\title{
Effect of Different Spacing on Growth and Yield of Sweet Potato
}

\author{
Shalini Badge*, G. B. Ganvir and Maya Raut \\ Agriculture Research Station, Sonapur- Gadchiroli, Maharastra, India \\ *Corresponding author
}

\section{A B S T R A C T}

\section{Keywords}

Sweet potato, Spacing, Tuber, Yield

\section{Article Info}

Accepted:

07 January 2021

Available Online:

10 February 2021
The present experiment is carried out at Agriculture research Station, Sonapur -Gadchiroli during the year 2019-20 with six different spacing $(60 \times 30,60 \times 45,90 \times 30,90 \times 45,120$ $\mathrm{cm} \times 30 \mathrm{~cm}$ and $120 \mathrm{~cm} \times 45 \mathrm{~cm}$ ) in Randomized block design with four replication, with the objective to determining the effect of plant spacing on the growth and yield of sweet potato. The results revealed that, maximum growth was recorded viz., vine length (149.10 $\mathrm{cm})$, and number of branches per vine (7.80) was recorded maximum in wider spacing $120 \mathrm{~cm} \mathrm{x} 45 \mathrm{~cm}$ however, the intermodal length of vine was found to be non significant. The maximum yield per vine was obtained in the wider spacing $120 \mathrm{~cm} \mathrm{x} 45 \mathrm{~cm}(405.48$ g). However, calculating the yield data per plot and per ha got different results. The maximum tuber yield per plot $(13.09 \mathrm{~kg})$ and per ha $(13.47 \mathrm{t})$ was recorded with the spacing of $60 \mathrm{~cm} \times 30 \mathrm{~cm}$ which was statistically at par with the spacing $90 \mathrm{~cm} \times 30 \mathrm{~cm}$ and $120 \mathrm{~cm} \times 30 \mathrm{~cm}$. Increasing plant density from 2 plants $\mathrm{m}^{-2}(120 \mathrm{~cm} \mathrm{x} 45 \mathrm{~cm})$ to higher level of 6 plants $\mathrm{m}^{-2}(60 \mathrm{~cm} \times 30 \mathrm{~cm})$ increased the production of total tuber yield from $13.47 \mathrm{t} \mathrm{ha}^{-1}$. In conclusion, the results of the study revealed that the highest plant density of 6.00 plants $\mathrm{m}^{-2}(60 \mathrm{~cm} \times 30 \mathrm{~cm})$ despite decreasing the yield per plant, resulted in the production of the highest tuber yields ha ${ }^{-1}$

\section{Introduction}

Among the tuber crops of the world, sweet potato [Ipomaea batatas (L.)] ranks third in importance after Iris potato and cassava (Ikeorgu, 2003) belongs to the family Convolvulaceae, It is a warm-season crop and grows best in abundant sunshine, temperatures above $24^{\circ} \mathrm{C}$, sandy loam soil and a well-distributed rainfall of 850-900 $\mathrm{mm}$ per annum. It matures in 3-4 months duration depending on the variety (Anonymous, 2003). It is a very nutritive vegetable, producing substantially high edible energy per hectare per day compared to rice, wheat, maize and cassava. It contains starch (12.7 g), sugar (4.2 $\mathrm{g})$, vitamin A (709 $\mu \mathrm{g})$ and protein $(1.6 \mathrm{~g})$ per $100 \mathrm{~g}$ of edible part (USDA, 2013). Sweet potato tuber is a major source of carbohydrate and can be eaten without processing. The succulent vines can also be eaten as vegetable to enrich dietary intake. In India, it is cultivated in almost all the states but major contribution comes from four states namely Bihar, Orissa, Uttar Pradesh, Madhya Pradesh, Maharashtra, Karnataka and Rajasthan. The area under sweet potato cultivation in India is 0.13 million ha with a 
production of 1.47 million tonnes (FAO, 2016). In spite of its importance as a food and vegetable, very little attention has been given on improved cultural practices i.e. spacing. Plant population is one of the most important factors contributions to higher yield of sweet potato (Sarkar, 1985). The yield of tuberous roots per plant increases with the increase in plant spacing (Mannan, 2009). Most farmers in the humid and sub-humid tropics grow the crop at wide and random spacing because of the prevailing intercropping system. Closer spacing may be preferred for sweet potato to achieve maximum tuber yield. According to Farooque et al., (1983) reported that increase in plant population increased total yield per unit area. It is therefore logical phenomena that, a adequate spacing may probably leads to greater crop yield through rapid attainment of ground cover for better interception of solar radiation and hence an increases in photosynthetic ability of crop. Scanty research works are available on the spacing in context of Maharashtra especially in Vidarbha. Therefore, it is need to find out optimum spacing for higher yield in sweet potato.

\section{Materials and Methods}

A field experiment was carried out at farm of Agriculture Research Station, Sonapur Gadchiroli during rabi season of the year 2019-2020. Mean annual rainfall of $1500 \mathrm{~mm}$ and daily mean temperature of 26 to $40^{\circ} \mathrm{C}$. The experiment was started early (October -
March) in the growing season. The experiment was laid out in a Randomized Block Design with four replications. The experiment comprised five plant spacing namely $60 \times 30,60 \times 45,90 \times 30,90 \times 45$, $120 \mathrm{~cm} \times 30 \mathrm{~cm}$ and $120 \mathrm{~cm} \mathrm{x} 45 \mathrm{~cm}$ corresponding to plant densities of 55555, 37037, 37037,24691, 27778 and 18518 plants per ha respectively. The experimental plot was ploughed and subsequent harrowing was done and soil was brought to fine tilth. At the time of land preparation, well rotted FYM @ $20 \mathrm{t} \mathrm{ha}^{-1}$ was mixed uniformly in the soil before last harrowing. Layout of broad furrow of a dimension $3.60 \mathrm{~m} \times 2.70 \mathrm{~m}$ was made. Row to row spacing and plant to plant spacing within the row was maintained as per treatments. Two vines sets of $30 \mathrm{~cm}$ length were planted per hill. Fifty per cent of the vine was inserted into the soil at acute angle to the ground. Two week after transplanting the crop was thinned to one vine per hill. 60 $\mathrm{kg} \mathrm{N}$ and $60 \mathrm{~kg} \mathrm{P}_{2} \mathrm{O}_{5} \mathrm{ha}^{-1}$ and $120 \mathrm{~kg} \mathrm{~K}_{2} \mathrm{O}$ was applied in the form of urea, SSP and murate of potash respectively. Half of $\mathrm{N}$, all $\mathrm{P}$ and $\mathrm{K}$ were applied at the time of land preparation remaining half dose of nitrogen were applied 30 days of planting.

Observations like vine length, number of branches, intermodal length of vine, length of tuber, diameter of tuber, number of tuber per plant, tuber yield per plant, per plot and per ha was recorded and data was statistically analyzed as per method suggested by Gomez and Gomez (1984).

\section{Plant population density}

\begin{tabular}{|c|c|c|}
\hline Spacing & Plant population $/ \mathbf{m}^{\mathbf{2}}$ & Plants population /ha \\
\hline $\mathbf{6 0} \times \mathbf{3 0} \mathbf{~ c m}$ & 6 & 55555 \\
\hline $\mathbf{6 0} \times \mathbf{4 5} \mathbf{~ c m}$ & 4 & 37037 \\
\hline $\mathbf{9 0} \times 30 \mathrm{~cm}$ & 4 & 37037 \\
\hline $\mathbf{9 0} \times \mathbf{4 5} \mathbf{~ c m}$ & 2 & 24691 \\
\hline $\mathbf{1 2 0} \times 30 \mathrm{~cm}$ & 3 & 27778 \\
\hline $\mathbf{1 2 0} 45 \mathbf{c m}$ & 2 & 18518 \\
\hline
\end{tabular}




\section{Results and Discussion}

\section{Growth parameter}

Data from table 1 showed that six different spacing were statistically significant in respect of growth parameter except intermodal length of sweet potato. Data from table 1 revealed that, vine length was varied significantly due to the variation of spacing. It ranged from $130.30 \mathrm{~cm}$ to $149.10 \mathrm{~cm}$. The maximum vine length was observed from the spacing of $120 \mathrm{~cm} \times 45 \mathrm{~cm}$ (S6) which was at par with spacing $120 \mathrm{~cm} \times 30 \mathrm{~cm}$. while the minimum length $(130.30 \mathrm{~cm})$ from the spacing of $60 \mathrm{~cm}$ x $30 \mathrm{~cm}$ (S1). Significantly maximum number of branches per vine (7.80) was recorded in wider spacing i.e. $120 \mathrm{~cm} \mathrm{x}$ $45 \mathrm{~cm}$ which was at par with spacing $120 \mathrm{~cm}$ $\mathrm{x} 30 \mathrm{~cm}$. However; minimum number of branches per vine (5.25) was recorded in spacing $60 \mathrm{~cm} \times 30 \mathrm{~cm}$. Inter nodal length of vine found to be non significant value. The vine under the treatment of $S 6(120 \mathrm{~cm} \mathrm{x} 45$ $\mathrm{cm}$ ) had enough space for vegetative growth and had less nutrition competition compared to other vines grown under the treatments $\mathrm{S} 1$ $(60 \mathrm{~cm} \times 45 \mathrm{~cm}), \mathrm{S} 2(60 \mathrm{~cm} \times 30 \mathrm{~cm})$ and $\mathrm{S} 3$ $(90 \mathrm{~cm} \times 45 \mathrm{~cm}), \mathrm{S}-4(90 \times 30 \mathrm{~cm})$ and $\mathrm{S} 5$ $(120 \mathrm{~cm} \times 30 \mathrm{~cm})$. This might be due to wider spacing helped the individual plant to utilize more water, nutrient, light and air. In closer spacing, the plant population per unit area was higher, which led to keen competition among the plants, resulting in poor growth. These results are in agreement with the results of Joshi (1987), Sounda et al., (1989) and Kumar et al., (2012) in radish, Shahana and Shahiduzzaman (2016) in sweet potato.

\section{Yield parameters}

Data from the table 2 significantly maximum length of tuber $(25.10 \mathrm{~cm})$ and diameter of tuber $(6.57 \mathrm{~cm})$ were recorded in spacing 120 $\mathrm{cm} \times 45 \mathrm{~cm}$ (S6) than other spacing. Minimum length of tuber $(22.05 \mathrm{~cm})$ and diameter of tuber $(4.56 \mathrm{~cm})$ was observed in spacing $60 \mathrm{~cm} \times 30 \mathrm{~cm}$. Similar results were observed by Nisha et al., (2020) and Sunita et al., (2017) in sweet potato.

Table.1 Effect of spacing on growth parameters of sweet potato

\begin{tabular}{|l|c|c|c|}
\hline Treatments & Vine length(cm) & No. of branches & Intermodal length (cm) \\
\hline T1: $\mathbf{6 0} \mathbf{~ c m ~ X ~ 3 0 ~ c m ~}$ & 130.30 & 5.25 & 0.87 \\
\hline T2: 60 cm X 45 cm & 135.10 & 5.60 & 0.86 \\
\hline T3: 90 cm X 30 cm & 134.10 & 6.00 & 1.22 \\
\hline T4: 90 cm X 45 cm & 133.85 & 6.65 & 1.18 \\
\hline T5: $\mathbf{1 2 0}$ cm X 30 cm & 141.80 & 6.95 & 1.35 \\
\hline T6: 120 cm X 45 cm & 149.10 & 7.80 & 1.35 \\
\hline “F” test & Sig. & Sig. & N.S. \\
\hline SE(m) & 3.03 & 0.31 & 0.07 \\
\hline CD at 5\% & 9.24 & 0.95 & - \\
\hline
\end{tabular}


Table.2 Effect of spacing on yield parameters of sweet potato

\begin{tabular}{|c|c|c|c|c|c|c|}
\hline Treatments & $\begin{array}{l}\text { length of } \\
\text { tuber } \\
(\mathrm{cm})\end{array}$ & $\begin{array}{l}\text { Diamete } \\
r \text { of } \\
\text { tuber } \\
(\mathrm{cm})\end{array}$ & $\begin{array}{l}\text { No. of } \\
\text { tuber }\end{array}$ & $\begin{array}{l}\text { Tuber yield } \\
\text { per vine } \\
\text { (g) }\end{array}$ & $\begin{array}{l}\text { Tuber } \\
\text { yield per } \\
\text { plot } \\
\text { (kg) }\end{array}$ & $\begin{array}{l}\text { Tuber yield } \\
\text { per ha } \\
\text { (t) }\end{array}$ \\
\hline T1: $60 \mathrm{~cm} \mathrm{X} 30 \mathrm{~cm}$ & 24.85 & 4.80 & 3.37 & 243.585 & 13.098 & 13.475 \\
\hline T2: $60 \mathrm{~cm} \mathrm{X} 45 \mathrm{~cm}$ & 26.80 & 4.56 & 3.05 & 256.710 & 9.242 & 9.508 \\
\hline T3: $90 \mathrm{~cm} \mathrm{X} 30 \mathrm{~cm}$ & 22.05 & 5.01 & 2.97 & 342.590 & 12.333 & 12.689 \\
\hline T4: $90 \mathrm{~cm} \mathrm{X} 45 \mathrm{~cm}$ & 29.85 & 5.56 & 3.33 & 373.790 & 8.721 & 9.229 \\
\hline T5: $120 \mathrm{~cm} \mathrm{X} 30 \mathrm{~cm}$ & 25.10 & 6.35 & 3.60 & 361.940 & 9.772 & 10.054 \\
\hline T6: $120 \mathrm{~cm} \mathrm{X} 45 \mathrm{~cm}$ & 22.75 & 6.57 & 4.13 & 405.480 & 7.299 & 7.509 \\
\hline "F" test & Sig & Sig & Sig. & Sig. & Sig. & Sig. \\
\hline SE(m) & 2.26 & 0.17 & 0.13 & 8.87 & 0.743 & 1.122 \\
\hline CD at $5 \%$ & 6.78 & 0.54 & 0.39 & 26.61 & 2.192 & 3.307 \\
\hline
\end{tabular}

Spacing $120 \quad \mathrm{~cm} \quad \mathrm{x} \quad 45 \quad \mathrm{~cm} \quad$ (S6) gave significantly maximum number of tuber (5.13) per vine which was followed by spacing $120 \mathrm{~cm}$ x $30 \mathrm{~cm}$. The minimum number of tuber per vine (2.97) was recorded in closer spacing i.e. $60 \mathrm{~cm} \times 30 \mathrm{~cm}$. Maximum number of tuber per vine might be due to the more land area available per plant. It showed that closer spacing produced comparatively less number of tubers. Abdissa et al., (2011) found that number of tuber was maximum in wider spacing.

Maximum yield of tuber per vine (405.48) was recorded in wider spacing $120 \mathrm{~cm} \mathrm{x} 45$ $\mathrm{cm}$ than other spacing. Minimum weight of tuber per vine $(243.58 \mathrm{~g})$ was recorded in closer spacing $60 \mathrm{~cm}$ x $30 \mathrm{~cm}$. However, significantly maximum tuber yield per plot $(13.09 \mathrm{~kg})$ and tuber yield $\mathrm{ha}^{-1}(13.47 \mathrm{t})$ were recorded under closer spacing S1 $(60 \mathrm{~cm}$ x 30 $\mathrm{cm})$ which was at par with spacing $90 \mathrm{~cm} \mathrm{x}$ $30 \mathrm{~cm}$ (S3) and $120 \mathrm{~cm}$ x $30 \mathrm{~cm}$ (S5). Similar result was observed by Nisha et al., (2020) in sweet potato. This could be due to more plant population per unit area. Generally as the plant spacing became closer and plant density higher, tuber weight plant $^{-1}$ decreased. By contrast, tuber yield, which was significantly influenced also by plant spacing increased progressively as plant spacing became closer and hence plant density higher. The tuber yield was lower per plots where the plants were spaced $120 \mathrm{~cm} \times 30 \mathrm{~cm}$ compared with those where the plants were spaced $60 \mathrm{~cm} \times$ $30 \mathrm{~cm}, 60 \mathrm{~cm} \times 45 \mathrm{~cm}$, and $90 \mathrm{~cm} \times 30 \mathrm{~cm}$. Similar finding were observed by Adubasim et al., (2017).

\section{References}

Abdissa, T., Chali, A., Tolessa, K., Tadese, K. and Awas, G. 2011. Yield and yield component of sweet potato as influenced by plant density in Adami Tulu Jido Kombolcha district, Central Rift Valley of Ethiopia. American J. Experimental Agriculture. 1(2): 40-48.

Adubasim, C.V., Law-Ogbomo, K.E. and Obalum, S.E. 2017. Sweet potato (Ipomoea batatas) growth and tuber yield as influenced by plant spacing on sandy loam in humid tropical environment. J. Tropical Agriculture, Food, Environment and Extension. 16 (3): $46-50$.

Anonymous. 2003. Treasure for the poor in sweet potato. CIP (International Potato Centre) Lime Peru. Pp. 25.

FAO STAT (2016). Food and Agriculture 
Organization of the United Nations. FAO Statistics Division.

Gomez, A.K. and Gomez, A.A. 1984. Statistical procedure for Agricultural Research. $2^{\text {nd }}$ Edition Awileg International publication, Singapur. pp. 20-25

Ikeorgu, J.E.G. (2003). Creating employment opportunities in the agro-allied subsector: The case of yam production. Bullion Magazine, pp. 15-22

Joshi, P.C. and Patil, N.S. 1992. Note on effect of plant density, nitrogen and phosphorous on yield of radish. Indian J. Hort. 149(3): 265-266.

Kumar, M., Kumar S., Kumar, P., Rathore, S.V.S., Singh, R.N and Singh S.K. 2012. Effect of steckling size and spacing on growth, yield and quality of radish seed cv. Pusa Rashmi. Progressive Agriculture. 12(1): 194 198.

Mannan, M.A.1984. Effect of plant spacing on the yield contributing characters and yield of sweet potato. Bangladesh Hort. 12 (1): 57-58.

Nisha Kumari Meena, Rathore, R. S. and Mithlesh Kumari, Meena. 2020. Effect of planting dates and plant spacing on growth and yield attributes of sweet potato (Ipomoea batatas (L.) Lam.) cv.CO-3-4. Int.J.Curr.Microbiol.App. Sci. 9(4): 2602-2608

Sarkar, AK.1985. Effect of plant density on yield of sweet potato. ARC Training, sweet potato. 1- 4. http://www.arcavrdc. org/pdf_files/Asit(3-N).pdf.

Shahana, Sultana and Shahiduzzaman, Md.. 2016. Effect of plant spacing on the growth and yield of sweet potato cultivars in medium highland condition under AEZ-9. International J. Applied Research. 2(3) 108-112

Sounda, G., Ghanti, P., Ghatak, S.1989. Effect of levels of nitrogen and different spacing on vegetative growth and yield of radish. Environmental Science and Ecology. 7(1):178-180

Sunita, Koodi, Singh, S.P., Manoj Kumar, Rolaniya and Prem Raj. 2017. The growth, yield and quality of sweet potato (Ipomoea batatas Lam.) Influenced by different plant densities International J. Chemical Studies. 5(4): 359-361

USDA. Data base. 2013. National nutrient data base for standard reference release

\section{How to cite this article:}

Shalini Badge, G. B. Ganvir and Maya Raut. 2021. Effect of Different Spacing on Growth and Yield of Sweet Potato. Int.J.Curr.Microbiol.App.Sci. 10(02): 643-647. doi: https://doi.org/10.20546/ijcmas.2021.1002.077 